\title{
Does Banking in Indonesia tend to be Concentrated?
}

\author{
Novita Kusuma Maharani ${ }^{1}$, Sumardi ${ }^{2}$, Auwal Salisu ${ }^{3}$ \\ University of Muhammadiyah Prof. DR. HAMKA ${ }^{1,2}$, Federal University Gashua, Yobe State \\ Nigeria $^{3}$ \\ novita.kusuma.m@uhamka.ac.id I \\ sumardi@uhamka.ac.id ${ }^{2}$ \\ ibnsalis2002@gmail.com ${ }^{3}$
}

\begin{abstract}
The banking in Indonesia has undergone several changes in the market structure that ultimately impacts the prevailing policies and regulations. This study aims to examine the impact of changes in the banking market structure identified through the level of market concentration in the banking environment and examine the factors that influence the level of concentration of the banking market from 2005 to 20I6. The study also examined the impact of changes in banking structure during the global crisis. The measurement of banking concentration used in this study is the Herfindahl-Hirschman Index (HHI). Furthermore, the influential factors consist of: (I) Bank specification, including bank size (Size), credit risk (NPL), profitability (ROE), banksoundness(CAR),(2)Market specification,namely the number of standingbank (NUM), and (3) Global crisis. The study used GLS (Generalized Least Square) method to detect autocorrelation on each variable. The results show that banks in Indonesia tended to have a low level of market concentration. The results are also in accordance with the SCP paradigm which states that banks tend to generate high profits when the level of banking market concentration is high.
\end{abstract}

Keywords : Market Concentration, Competition, Dual-Banking, Bank Specification, Market Specification, Global Crisis.

\section{A. INTRODUCTION}

The banking in Indonesia has undergone several changes in the market structure that ultimately impacts the prevailing policies and regulations. This triggered the change in the banking structure over time. The change in Indonesia's banking structure has passed several phases. In 1980s, Indonesian banking was deregulated where the policy gave ease in the establishment of a bank in Indonesia. Furthermore, there is also a financial liberalization where the policy begins to permit private banks and foreign banks to operate(Sato, 2005). In I99I, the establishment of a sharia-based public bank was established by the Indonesian Ulama Council (MUI) and Indonesian entrepreneurs with the name of Bank Muamalat Indonesia (BMI) which was followed by other public banks that started to establish sharia-based banks.

Received : September I8,2019 - Revised : December 02, 2019 - Accepted : January 08, 2020 University of Muhammadiyah Prof. DR. HAMKA ${ }^{1,2}$, Federal University Gashua, Yobe State Nigeria $^{3}$

E-mail :novita.kusuma.m@,uhamka.ac.id',sumardi@,uhamka.ac.id², ibnsalis2002@gmail.com $^{3}$ 
In the next phase, in 1997-1998, Indonesia suffered an economic crisis that had an impact on the fall of global financial markets. Most of the banks have difficulty in liquidity due to not insufficient capital, then the value of the bank's assets decreases so that many banks will be liquidated because they cannot survive. To overcome the crisis, a consolidated policy was made to improve the public's confidence in Indonesian banking. The changes continued until the introduction of the Indonesian Banking Architecture Policy (API) in 2004 as the basic framework of the Indonesian banking system. The API policy makes several banks merge and conducts acquisitions in the interest of liquidity and bank efficiency. So in recent years, the number of banks in Indonesia has decreased(Pujianti, 2016).

Market forces in the banking sector reflects the structure of the market. The decreasing number of banks leads to low interbank competition. This can result in increased profitability, and banks tend to be concentrated, thus distancing banks in a perfect category of market structures. When banking is increasingly concentrated, its impact will also be felt by the stability of banking (Mamatzakis, E, Staikouras, C, \& Fillipaki, 2005). In addition, more concentrated banking is considered more fragile, similar to the concept of "too big to Fail" (Mamatzakis, E, Staikouras, C, \& Fillipaki, 2005)The results of the study conducted by (Nafisah, M, Ismail, G.A, \& Muhammad, 20I5)which analyzes the relationship between concentration and competition in sharia banks and conventional banks in Malaysia indicate the difference in concentration ratio and trend decline over time. (Ariss, 2010) tested competition levels at Sharia banks and conventional banks in 13 countries using structural (HHI) and non-structural approaches $(\mathrm{H}-$ Statistic and Lerner index), and found that sharia banks concentrated higher if Compared to conventional banks.

Based on the understanding, this research seeks to investigate the impact of the structural changes of banking in Indonesia with the period of observation from 2005 to 2016. This research will focus on several issues. Firstly, to test the level of banking concentration implementing a dual-banking system where sharia banks and conventional banks coexist. Secondly, to test the determinant of concentration that can affect the magnitude of the banking concentration in Indonesia. Third, test the determinant of the concentration when Indonesia suffered a global crisis in 2008 . 


\section{B. THEORITICAL}

\section{The Market Structure of Indonesian Banking}

Market structures reflect the price level within the market, which greatly affects the behaviour and performance of an industry. (Sinansari, P, Priyarsono, DS, \& Supriyatno, 2015)defines market structures as a classification of forming procedures into several markets based on characteristics such as the type of products, the number of companies in the industry, and the role of marketing in the industrial activities. In general, the classification of market structures is divided into two parts, namely: the perfect competition market and the imperfect competition market(Hendra, N.T.S, \& Hartomo, 2017). The competition market perfectly indicates the market form where there are many sellers and buyers, and the products are homogeneous. Meanwhile, the imperfect competition market is a form of market where it is not perfectly organized. These types of competitive markets are not perfect, consisting of monopoly, oligopoly, and monopolistic competition.

Indonesian banking has undergone several changes in the market structure that ultimately impacts the prevailing policies and regulations. This triggered the change in the banking structure over time. The change in Indonesia's banking structure has passed several phases. In the range of the I980s, Indonesian banking was deregulated where the policy gave ease in the establishment of a bank in Indonesia, and triggered the number of banks that are surviving today. Then, financial liberalization arose where the policy began to permit private banks and foreign banks to operate (Sato, 2005). Furthermore, the establishment of a shariabased public bank was established in I99I, and began to operate in I992 by the Indonesian Ulama Council (MUI) and Indonesian businessmen group under the name of Bank Muamalat Indonesia (BMI). The establishment of BMI was further followed by other public banks that started to establish sharia banks.

The next phase, in 1997-I998, Indonesia suffered an economic crisis that impacted the fall of global financial markets and caused the collapse of Indonesian banking. Most of the banks have difficulties in liquidity because they do not have capital adequacy, the value of the bank's assets has also decreased so that many banks are liquidated because they cannot survive. To address the crisis, a consolidation policy was conducted by the Indonesian Government and the International Monetary Fund (IMF), which aims to increase the public's confidence in Indonesian banking. The change continued until the introduction of the Indonesian Banking Architecture Policy (API) in 2004 as the basic framework of the Indonesian banking system. The API policy directly affects the structure and banking competitions formulated through two policies: (I) 
Minimum Capital amount in PBI No. I0/I5/PBI/2005, and (2) Single ownership policy on PBI No. 8/16/PBI/2006. API policies have made several mergers and acquisitions in the interest of liquidity and bank efficiency. So, in recent years, the number of banks in Indonesia has decreased(Pujianti, 2016).

\section{Concentration and Competitions}

Concentration is the possession or control of a large number of economic resources by a small number of economic units(Sinansari, P, Priyarsono, DS, \& Supriyatno, 2015), so that some small economic units have the authority to control the market that can increase their operating activities. The high concentration of the market is also related to the low level of socio-economic welfare due to the price behavior in the market that charges a higher price at the bank's service level. In addition, more concentrated banking is considered more "fragile", similar to the concept of "too big to fail". The issue of the banking concentration level is also often associated with the banking competition level. Some studies have said that the level of concentration and competition has the opposite relationship. The implications of the statement are based on theoretical statements in which the more concentrated a market will reflect the low competition conditions due to the weakness in market power (Mamatzakis, E, Staikouras, C, \& Fillipaki, 2005).

Concentration and competition level measurements have been described in previous literatures where there are two approaches used (Bikker, A, Shaffer, A, \& Spierdijk, 2009; Maharani, N.K, \& Setiyono, 20I8) : (I) The structuring approach, referring to the paradigm of Structure Conduct Performance (SCP) and Efficiency Hypothesis. The SCP paradigm states that high-concentrated markets tend to be colusive. This suggests that the performance of the market relies heavily on the market structure; While the efficiency hypothesis assess large banks that are efficient in driving performance improvements. The method used by this approach is a measurement of the bank's concentration, namely HerfindhalHirschman Index (HHI). (2) The Non-structural approach, this approach is based on the concept of the New Empirical Industrial Organization (NEIO) which reveals that a bank in the perfect market as well as an imperfect market has a different reaction to the change of demand and supply. This approach measures competition and emphasizes the behavioral analysis of bank competitions without using explicit information about the market structure. Then, measurements for the non-structural approach used H-Statistic proxies, the Lerner index, and the Boone indicator. 


\section{Previous Studies}

The study conducted by (Nafisah, M, Ismail, G.A, \& Muhammad, 20I5) is a study that analyzes the relationship between concentration and competition in sharia banks and conventional banks in Malaysia, as well as specific factors that influence it. The measurements in the study used a structural approach, and the results supported the SCP paradigm, in which the difference in concentration ratios indicated a trend decline over time and reflected the magnitude of the competition in Sharia banks and conventional banks in Malaysia. Another study that found that there was a concentrated bank tendency is (Sinansari, P, Priyarsono, DS, \& Supriyatno, 20I5)which found that the banking structure in Indonesia can be classified oligopoly structures controlled by several major banks. The oligopoly structure affects banking behavior by establishing a branch office so that it has the power to better reach the market. In addition, the magnitude of banking assets has become an important and significant factor in the change in the banking structure in Indonesia.

(Ariss, 2010) tested competition levels at Sharia banks and conventional banks in 13 countries using structural (HHI) and non-structural approaches (HStatistic and Lerner index). Results found that sharia banks had higher concentrations when compared to conventional banks. The study also showed that high levels of the bank's concentration were positively related to the level of profitability after each country's control. Subsequently, (Mamatzakis, E, Staikouras, C, \& Fillipaki, 2005) analyzed the level of concentration and competition with non-structural measurements (H-Statistic) on the banks in Southeast Europe and found that banks in Southeast Europe could be categorized under monopolistic conditions. The testing of banking concentrations towards the risk of banks was conducted by (Hendra, N.T.S, \& Hartomo, 2017), and they found that there was a positive relationship between the concentration and risk of banks. These results indicate that high concentrated banks have a greater level of risk compared to low-concentration banks.

(Widyastuti, S.R, \& Armanto, 2013) identified the level of competition for the Indonesian banking industry before and after the introduction of the policy of Indonesian Banking Architecture (API). The result of the identification stated that the level of banking competition decreased after API policy introduction. This triggers a banking tendency that starts to be concentrated and leads to the market structure of monopoly or colusive oligopoly. Analyzed the influence of market structure on the profitability level of sharia banking in Indonesia. The results of the analysis reveal that the SCP theory does not apply to Indonesian sharia banking, where the change of the market structure does not affect sharia 
banking profitability. Subsequent findings show that sharia banking in Indonesia tends to be concentrated with a concentration ratio above $45 \%$.

The level of bank concentration can also affect financial stability. Based on this issue, previous researchers categorized it into 2 different hypotheses. Concentration-stability, where banks having a low concentration level are more susceptible to financial crises than banks that have high concentration and, concentration-fragility states otherwise that, concentrated banks are more susceptible to the effects of the crisis which results in economic instability. (Yudaruddin, 20I4) tested the relationship of concentration with financial stability and found that banks in Indonesia tended to support the concentrationstability hypothesis where the higher the concentration of a bank, the stronger the financial stability of a country. This can be reflected in the resilience of a country if it experiences a financial crisis.

\section{METHODOLOGY}

This research uses conventional bank data and sharia banks with unbalanced panels. The use of data panels aims to capture the characteristics of each individual bank. The samples in this study are all conventional banks and Sharia banks operating in Indonesia. The period used is from 2005 to 2016 using the bank's annual data. The technique used is purposive sampling, which is a predetermined sample of the researcher. The source of the research data comes from Orbis Bank Focus which is published by Bureau Van Dijk, Indonesian Banking statistics (OJK), and Bank Indonesia.

The analytical tools in this study used the STATA I3.0. The analytical techniques that were used in this study consist of several phases i.e. descriptive statistical test, correlation test, and multiple regression test with GLS estimation method. To test each hypothesis, this study used the GLS (Genealized Least Square) estimation method by first performing a classic assumption test for the equation to be hypothesized. This method is an extension method of OLS that was developed to overcome the presence of heteroskedastisity symptoms so that the estimator is not biased and remains consistent. Here are the empirical models used:

$$
\text { HHI }_{i t}=\propto_{1}+\beta_{1} \text { BankSpec }_{i t}+\beta_{2} \text { MarketSpec }_{i t}+\beta_{3} D_{-} \text {Crisis }+\varepsilon_{i t}
$$

Notes :

HHI : Bank Consentration

BankSpec : Bank Specification (CAR, ROE, NPL, Size)

MarketSpec : Market Specification (NUM)

D_Crisis : Dummy Krisis 


\section{RESULTS AND DISCUSSION}

\section{Descriptive Statistics}

This research presents the results of the descriptive statistics for each of the variables in the time period of 2006 to 20I6. Table I shows that the average value of $\mathrm{HHI}$ for the entire sample is $8 \%$. The value indicates that the level of market concentration in Indonesian banking tends to be less concentrated. Furthermore, the value of CAR score has an average value of I, which means that the average bank in Indonesia is categorized as a very healthy bank. The ROE reflects the average level of profitability held by the bank in the range from 2006 to 2016 which is worth an average of $10 \%$. This indicates that the average profit level that each bank has is based on its own equity, which is fairly high. Furthermore, the mean value in the NPL which is a proxy of credit risk is at a range of $2 \%$. The average rate in the overall sample for the variable size (company size) measured by the total assets was $R p$ 7,600 million. Then, the average value for NUM (bank number) is I2I banks, which means that a period range of 2006 to 2016 has a considerable number of banks standing, and many branches of foreign banks are entering into the Indonesian banking market. For the crisis, the mean value is $9 \%$, in which the impact of the global crisis period of 2006 to 2016 was only experienced by Indonesia in the year 2008 .

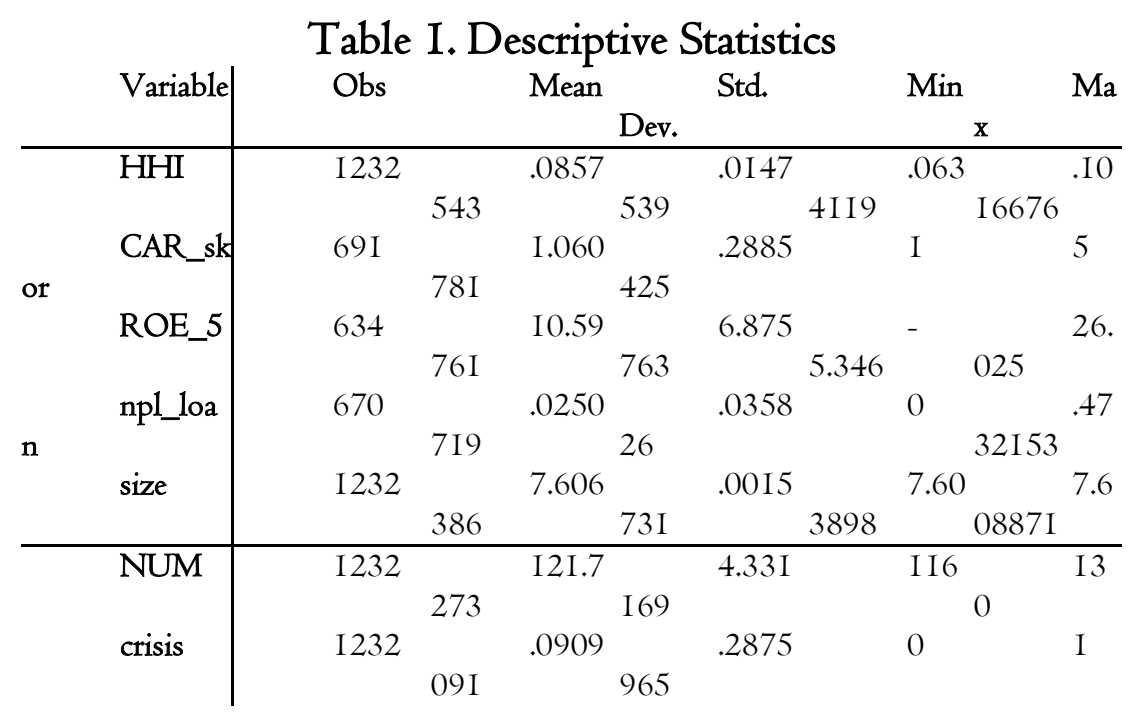

\section{The Market Consentration Level of Indonesian Banking}

In table 2, there is a level of concentration on Indonesian banking from 2006 to 2016. The concentration level is measured using the HerfindhalHirschman Index (HHI) resulting from a market share calculation. 
Table 2. The Market Consentration Level of Indonesian Banking

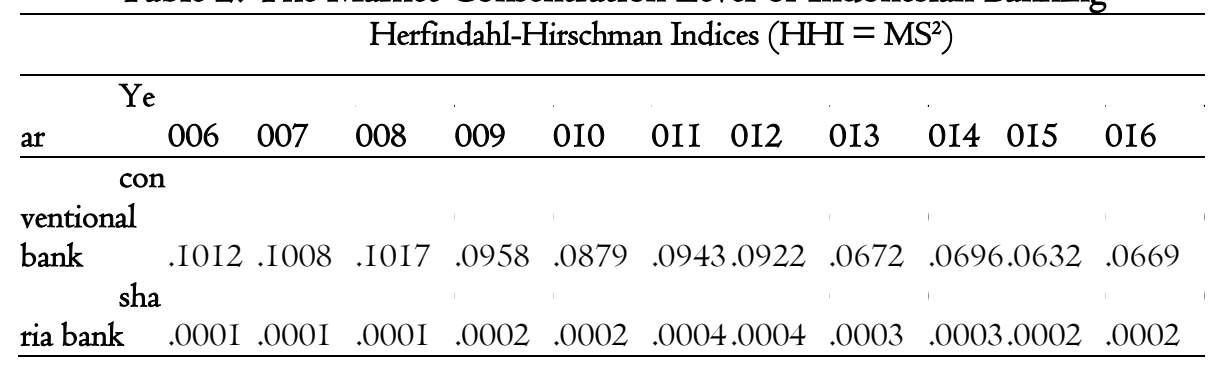

The table shows that there is a change in the market structure that shows the trend of declining concentrations in conventional banks where the value of HHI at the end of the year 2016 is 0.06 , or it can be said that Indonesia's conventional bank is not Concentrated. Whereas in Sharia banks, HHI trends show a value of 0 in almost the entire period meaning that sharia banks tend to be not concentrated or have higher levels of competition.

\section{Hyphothesis Testing Result}

The study uses the GLS (Generalized Least Square) method to test the relationships between the research variables with the analysis tool using the STATA 13.0. In table 3, the results showed the results of the market concentration level test associated with the variable bank specification (ROE, Size, CAR), Market Specification (NUM) and several variables that became research control (NPL and Risk Averse). The test was conducted by separating the bank's specialty of conventional banks (Model I and 2) and Sharia banks (models 3 and 4).

Meanwhile, test results on conventional banks indicate the ROE variable which is a proxy of the bank's profitability of positive and significant value at I0\% (model I) and 5\% (Model 2). This indicates that the higher the concentration rate of a bank, the higher the profitability it has. This results in line with the research of Mohammed DKK (2015) high-centralised banks have the ability to generate high returns on the banking market. However, ROE generates negative values that are not significant in Sharia bank samples (models 3 and 4) where the consentration rate of banking markets does not have any influence on the ability of Sharia Banks in making profits.

\section{Table 3. Hyphothesis Testing Results}

\begin{tabular}{llll}
\hline $\begin{array}{l}\text { (I) } \\
\text { Conventional Bank }\end{array}$ & $\begin{array}{l}\text { (2) } \\
\text { Sharia Bank }\end{array}$ & $(4)$ \\
\hline HHIt & HHIt & HHIt & HHIt \\
\hline
\end{tabular}




\begin{tabular}{|c|c|c|c|c|c|}
\hline & ROEit & $\begin{array}{l}0.000 I^{*} \\
(0.054)\end{array}$ & $\begin{array}{l}0.000 I^{2} \\
(0.013)\end{array}$ & $\begin{array}{l}-0.0000 \\
(0.912) \\
\end{array}$ & $\begin{array}{l}-0.0000 \\
(0.945) \\
\end{array}$ \\
\hline \multirow{2}{*}{\multicolumn{2}{|c|}{ Sizeit }} & $-8.6028^{\prime}$ & $-8.6017^{\prime}$ & -15.039 & -15.096 \\
\hline & & $(0.000)$ & $(0.000)$ & $(0.000)$ & $(0.000)$ \\
\hline \multirow{2}{*}{\multicolumn{2}{|c|}{ CARit }} & 0.0025 & 0.0025 & $-0.002 \mathrm{I}$ & -0.0024 \\
\hline & & $(0.22 \mathrm{I})$ & $(0.219)$ & $(0.439)$ & $(0.4 \mathrm{I} 4)$ \\
\hline \multirow{2}{*}{\multicolumn{2}{|c|}{ NUMt }} & -0.0000 & -0.0000 & $-0.0037^{-1}$ & -0.0037 \\
\hline & & $(0.68 \mathrm{I})$ & $(0.696)$ & $(0.000)$ & $(0.000)$ \\
\hline \multirow{2}{*}{\multicolumn{2}{|c|}{ Crisis }} & -0.0004 & 0.0018 & -0.0004 & $-0.001 \mathrm{I}$ \\
\hline & & $(0.826)$ & $(0.582)$ & $(0.928)$ & $(0.8 \mathrm{I} 4)$ \\
\hline & Crisis $\quad x$ & & -0.0002 & & \\
\hline \multirow{3}{*}{ ROEit } & & & $(0.423)$ & & \\
\hline & NPLit & $0.027^{\prime}$ & $0.026 \mathrm{I}$ & & \\
\hline & & $(0.046)$ & $(0.063)$ & & \\
\hline & Risk & & & $0.000 I^{x}$ & $0.000 I^{\prime}$ \\
\hline \multicolumn{2}{|c|}{ Averse } & & & $(0.003)$ & $(0.8 \mathrm{I} 4)$ \\
\hline & $\mathrm{C}$ & $65.522^{\ldots}$ & 65.513 & I I $4.940^{\prime}$ & I I $5.363^{-}$ \\
\hline & & $(0.000)$ & $(0.000)$ & $(0.000)$ & $(0.000)$ \\
\hline on & Observati & 232 & 232 & 46 & 40 \\
\hline
\end{tabular}

Table 3. The result of the hypothesis test with the GLS-ROE method is a proxy of bank profitability. "Size " is the size of the company acquired from the total asset log. CAR indicates the level of health of banks measured through the magnitude of the capital owned. NUM is the number of banks standing in the research period. Crisis is a proxy of the period of global crisis (crisis $=I$, non crisis $=0$ ). Crisis $x$ ROE is an interaction between bank profitability and crises. The control variable consists of the NPL proxy of credit risk, and the Risk Averse calculated from the equity divided by the total assets. The significant Level is *** $\mathrm{p}<0.0 \mathrm{I},{ }^{* *} \mathrm{p}<0.05,{ }^{*} \mathrm{p}<0$.

Next, the variable coefficient value "Size" shows negative results in the overall model and the significant level is $\mathrm{I} \%$. "Size " is a proxy bank size calculated using the natural logarithmic of the total assets of each bank. The results showed that Indonesia's banking looks more efficient in competitive market conditions when compared to the concentrated market. The value of the CAR coefficient has a positive value in conventional and negative banks in sharia banks but not significant. This indicates that the level of health of the bank represented by CAR does not have a significant effect on changing market conditions. As for market-specific variables that are proscribed by the number of banks (NUM), it generates a negative coefficient value in the overall model and is significant in Sharia bank samples (models 3 and 4). These results are consistent 
theories where increasing the number of banks will lower the concentration level and increase the presence of competitive conditions in the market.

The research tried to test the impact of market concentrations associated with the global crisis in 2008. Results show negative values (models I, 3, and 4) in which banks with high concentrations of markets are resistant to the global crisis. This results in favor of the pro-concentration theory that mentions that less concentrated banking markets are more prone to crisis when compared to highconcentrated banking markets with some major banks in them. Then, the bank control variable, NPL, which is the proxy of the bank's credit risk, shows a positive value (model 2) and is significant (model I). The possibility of high credit risk tends to emerge in the concentrated banking market. Furthermore, the Risk Averse control variable representing risk avoidance shows positive and significant results, in which the bank behaves to avoid risk in a concentrated banking market.

\section{E. CONCLUSION}

The research examines the changing of the banking market structure by focusing on the measurement of the banking concentration level and the determination of some of the variables that affect the level of the banking market in Indonesia that embrace the system of Dual-banking where conventional banks and sharia banks coexist. The study also tested the impact of the 2008 global crisis on the banking concentration level. Banking in Indonesia is found to have a low market concentration level. These results are indicated by the value of the $\mathrm{HHI}$ index being in the range of $<\mathrm{I}$ or equal to unconcentrated. The rise of the bank's position with private, government and foreign ownership is one of the factors that can lower the level of concentration in the Indonesian banking market. So, what happens is the opposite, where Indonesian banking tends to behave competitively with high interbank competition rates.

The test results are in accordance with the paradigm of SCP which states that banks tend to be able to generate high returns during high levels of banking market concentrations, especially in conventional banking. Furthermore, major banks can be more efficient in using assets when market conditions are concentrated high. It supports the theory of Efficiency Hypothesis where banks can have the efficiency to drive performance improvements (Bikker, A, Shaffer, A, \& Spierdijk, 2009; Lubis, 2012; Maharani, N.K, \& Setiyono, 2018). The number of banks is also a factor that can reduce the level of concentration of the banking market and can generate a high level of bank competition. The impact of the global crisis can also affect the changing conditions of the banking market where a 
country with concentrated banking conditions will be more immune to the crisis because the banks are doing better diversification. Therefore, minimizing the bank can make a country more vulnerable to the crisis.

\section{REFERENCES}

Ariss, T. R. (2010). Competitive Condition in Islamic and Conventional Banking: A Global Perspective. Review of Financial Economics. I9 (20I0). Page IOI-IO8.

Bikker, A, Shaffer, A, \& Spierdijk, L. (2009). Assessing Competition with the Panzar-Rose Model: The Role of Scale, Costs, and Equilibrium. Review of Economics and Statistics. January 2009.

Hendra, N.T.S, \& Hartomo, D. . (2017). Pengaruh Konsentrasi dan Pangsa Pasar Terhadap Pengambilan Risiko Bank. Jurnal Bisnis \& Manajemen. Vol. I7, No. 2, 2017. Page 35-50.

Lubis, F. A. (2012). Market Power Perbankan Indonesia. Buletin Ekonomi Moneter Dan Perbankan. Januari 2012.

Maharani, N.K, \& Setiyono, B. (2018). Do Risk, Business Cycle, and Competition Affect Capital Buffer? An Empirical Study on Islamic Banking in ASEAN and MENA. Journal of Islamic Monetary Economics and Finance. Vol 3, No. 2 (2018) February.

Mamatzakis, E, Staikouras, C, \& Fillipaki, N. (2005). Competition and Concentration in the Banking Sector of the South Eastern European Region. Emerging Markets Review. 6. (2005). Page 192-209.

Nafisah, M, Ismail, G.A, \& Muhammad, J. (20I5). No TitleaEvidence on Market Concentration in Malaysian Dual Banking System. Procedia-Social and Behavioral Finance. I72 (2015). Page I69-I76.

Pujianti, R. (2016). Analisis Struktur Pasar Perbankan dan Stabilitas Perbankan di Indonesia (Sebelum dan Sesudah Kebijakan Arsitektur Perbankan Indonesia). Jurnal Ekonomi Pembangunan. Vol. 5, No. 2. Juli 20I6. Page $217-238$.

Sato, Y. (2005). Bank Restructuring and Financial Institution Reform in Indonesia. The Developing Economics. XLIII-I. Maret 2005. Page 9I-I20.

Sinansari, P, Priyarsono, DS, \& Supriyatno, G. (2015). Analysis of Indonesia Banking Structure. International Journal of Science and Research. Vol. 6. Juli 2017.

Widyastuti, S.R, \& Armanto, B. (2013). Banking Industry Competition in Indonesia. 
Does Banking in Indonesia tend to be Concentrated?

Novita Kusuma Maharani ${ }^{1}$, Sumardi², Auwal Salisu ${ }^{3}$

Yudaruddin, R. (20I4). Dampak Tingkat KonsentrasiTerhadapKinerja dan StabilitasPerbankan di Indonesia tahun 2003-2013. Jurnalkeuangan Dan Perbankan. Vol. I8, No. 2 Mei 20I4. 278-286. 